\title{
Yetişkinlerin Yaşam Doyumu, Yalnızlık ve Öz-tiksinme Düzeyleri Arasındaki İlişkinin İncelenmesi
}

\author{
Selahattin AVŞAROĞLU ${ }^{1}$, Ayrahat HUDAYNAZAROVA², \\ Sidıka NURKOYUNCU ${ }^{3}$ ve Refika BAȘARIKAN ${ }^{4}$
}

Öz

Bu çalışmada, yetişkinlerin yaşam doyumu, yalnızlık ve öz-tiksinme düzeyleri arasındaki ilişkinin incelenmesi amaçlanmıştır. Yaşam doyumu, yalnızlık ve öz-tiksinme arasındaki ilişsi düzeyi, cinsiyet, eğitim durumu, medeni durum, gelir düzeyi, herhangi bir işte çalışı çalışmama durumu gibi değişkenlerde incelenmiştir. Araştırmanın modeli nicel araştırma yöntemlerinden ilişkisel tarama tekniği kullanılarak desenlenmiștir. Araștırmanın toplam katılımcı savısı, (kadın=353; erkek=281) olmak üzere toplamda 634 yetişkin bireydir. Veri toplama araçları olarak "UCLA Yalnızlık Ölçeği Kısa Formu”, "Yaşam Doyumu Ölçeğı", "Öz-tiksinme Ölçeği” ve çalıșmayı yürüten araștırmacılar tarafindan geliștirilen "Kișisel Bilgi Formu” kullanılmıştır. Araștırmada veriler, Google Forms üzerinden 2019 yllı içerisinde toplanmış olup, analizi için SPSS 22.00 paket programı kullanılmıştır. Elde edilen veriler ıșığında; yașam doyumu ile yalnızlık arasında anlamlı bir ilișki olduğu görülürken, yașam doyumu ve öz-tiksinme arasında ters yönlü bir ilişki olduğu saptanmıştır. Yapılan analizler sonucunda, yalnızlık ve öz-tiksinmenin yaşam doyumu üzerindeki etkisinin anlamlı olduğu ortaya çıkmıştır. Cinsiyete göre erkeklerin yaşam doyumunun, kadınlardan anlamlı düzeyde farklılaştı̆̆1 görülmüştür. Medeni duruma göre ise evlilerin yaşam doyumunun bekârlardan anlamlı düzeyde farklılaştı̆̆ sonucuna ulaşılmıştır. Bireylerin çalışma durumuna göre ise; iş sahibi olanlar ile olmayanlar arasında, işs sahibi olanlar lehine anlamlı bir farklılığın mevcut olduğu sonucuna ulaşılmıştır. Bireylerin gelir düzeyine göre ise gelir düzeyi fazla olanların yaşam doyumlarının daha yüksek olduğu sonucuna varılmıştır. Eğitim seviyesi arttıkça yaşam doyumunun arttığ ve yalnızlığın azaldığı sonucuna varılmıştır. Araştırma bulgularının alana katkı sağlayacağı umulmaktadır.

Anabtar Kelimeler: Yaşam Doyumu, Yalnızlık, Öz-Tiksinme

\section{Examining the Relationship between Adult Life Satisfaction, Loneliness and Self -}

\section{Disgust Levels}

\begin{abstract}
In this study, it was aimed to investigate the relationship between adult's life satisfaction, loneliness and self-disgust levels. The level of relationship between life satisfaction, loneliness and self-disgust is examined in variables such as gender, educational status, marital status, income level, whether or not to work in any job. The model of the study was designed by using relational scanning technique, which is one of the quantitative research methods. The total number of participants of the research is 634 adult individuals (female $=353$; male $=281$ ). "UCLA Loneliness Scale Short Form", "Life Satisfaction Scale", "Self-Disgust Scale" and "Personal Information Form" developed by researchers were used as data collection tools. In the research, the data were collected through Google Forms in 2019 and SPSS 22.00 package program was used for analysis. In the light of the data obtained; While there was a significant relationship between life satisfaction and loneliness, there was an inverse relationship between life satisfaction and self-disgust. As a result of the analyzes, it was revealed that the effect of loneliness and self-disgust on life satisfaction was significant. It has been observed that male satisfaction of life differs significantly from female according to gender. According to marital status, it is concluded that the life satisfaction of the married people differs significantly from the singles. According to the working status of the individuals, it is concluded that there is a meaningful difference between those who have a job and those who do not have a favor. According to the income level of the individuals, it was concluded that those with higher income have higher life satisfaction. It was concluded that as the level of education increases, satisfaction with life increases and loneliness decreases. It is hoped that the research findings will be original and contribute to the field.
\end{abstract}

Key Words: Life Satisfaction, Loneliness, Self-Disgust

\section{Atıf İçin / Please Cite As:}

Avşaroğlu, S., Hudaynazarova, A., Nurkoyuncu, S. ve Başarıkan, R. (2021). Yetişkinlerin yaşam doyumu, yalnızlık ve öz-tiksinme düzeyleri arasındaki ilişkinin incelenmesi. Manas Sosyal Araştırmalar Dergisi, 10(1), 183-198.

Geliş Tarihi / Received Date: 19.10.2020

Kabul Tarihi / Accepted Date: 04.12.2020

\footnotetext{
${ }_{1}$ Prof. Dr. - N. E. Üniversitesi Ahmet Keleşoğlu Eğitim Fakültesi, seloavsar@gmail.com

(D) ORCID: 0000-0002-0953-2922
}

2 Yüksek Lisans Öğrencisi - N. E. Üniversitesi Eğitim Bilimleri Enstitüsü, ayrahat.hudaynazarova@gmail.com

(iD ORCID: 0000-0001-8391-4286

${ }^{3}$ Yüksek Lisans Öğrencisi, N. E. Üniversitesi Eğitim Bilimleri Enstitüsü, sdknurkoyuncu@gmail.com

(iD) ORCID: 0000-0003-3372-1691

4 Yüksek Lisans Öğrencisi, N. E. Üniversitesi Eğitim Bilimleri Enstitüsü, refisbasarikan@gmail.com 


\section{Giriş}

İnsanların erdemlerine ve güçlü yanlarına dikkat çeken ve iyi yaşam nedir? sorusuna cevap arayan pozitif psikoloji kavramlarından birisi de yaşam doyumudur. Diğer bir pozitif psikoloji kavramı olan iyi oluş (Demirci ve Ekşi, 2015, s. 10) ise öznel iyi oluş (Eryllmaz ve Ögüulmüş, 2010, s. 190) kavramı içerisinde araştırılmakta, mutluluk yaşam doyumu bağlamında ölçülmeye çalışılmaktadır (Dağlı ve Baysal, 2016, s. 1251). Alan yazına bakıldığında yaşam doyumu kavramı çoğunlukla "öznel iyi oluş" yapısı altında bilişsel bir bileşen olarak incelenmektedir (Avşaroğlu ve Okutan, 2018, s. 62). Öznel iyi oluş, insanların hayatlarına yönelik tüm tepkilerini ve değerlendirmelerini, iyi gittiğini düşünme ve hissetme derecesini yansıtır (Uygur, 2018, s. 17; Singh ve Jha, 2008, s. 40). Bilim dünyasının yaşam doyumunun kaynaklarını bulmaya yönelik çabası söz konusudur (Özkul ve Alparslan, 2019, s. 3274). Mutluluk; kişinin geçmişte, gelecekte ve şimdiki zamandaki doyumu ile hayattaki değişim arzu ve çevresindekilerin görüşleri ile ilgili algısıyla alakalıdır (Diener vd., 1999, s. 277; Yalçın, 2015, s. 27). İş, benlik, aile, sağılk durumu ve para kişiler için doyum alanlarıdır (Diener vd.,1999, s. 277). Hayat inişleri çıkışları olan bir serüvendir. Bu serüvende bireyin yaşamından ne derece doyum sağladığ ve bu doyumu arttırabilmenin yollarının bulunması çok önemli görülmektedir. Yaşadığımız zaman diliminde insanlar, çeşitli zorluklarla yaşamını devam ettirmektedirler (Ülker Tümlü ve Recepoğlu, 2013, s. 206). Bu zorluklar bireyin psikolojisini etkilerken aynı zamanda bireyi çaresiz, zayıf ve savunmasız hale getirebilir (Avşaroğlu vd., 2005, s. 116). İş, aile ve kültürel yaşantılarda meydana gelen başarısızlıklar da bireyi tükenmişlik seviyesine getirebilmektedir. Bireylerin ilişkilerinde, yetersiz ve bireysel olarak tatmin edici olmayan sosyal deneyimler geçirmesi, hayatlarını farklı düzeylerde etkileyebilir (Çevik ve Korkmaz, 2014, s. 127). Bu da bireylerin kendilerini toplumdan soyutlamasına ve kendilerini yalnız hissetmelerine neden olabilmektedir (Buluş, 1997, s. 82-83). Yaşantısal olumsuzluklar bazen de depresif karakterdeki tiksinme gibi problemleri de beraberinde getirebilmektedir (Çeçen, 2008b, s. 20). Yapılan bu araştırmanın öncelikli amacı, yaşam doyumunun kaynaklarını bulma noktasında alanyazına katlı sağlamaktır. Bu çalısmada yaşam doyumu, yalnızlık ve öztiksinme kavramları ayrnntılı olarak ele alınacaktır.

Pozitif psikoloji çalısmalarında sıklıkla öne çıkan kavramlardan biri de yaşam doyumudur (Ümmet, 2017, s. 160). "Yaşam doyumu" kavramı, ilk kez 1961 yılında Neugarten tarafindan tanımlanmıştır (Şahin, 2019, s. 157). Doyum; insanların açlık, susuzluk, cinsellik vb. temel biyolojik ihtiyaçlarının veya merak, sevgi, samimiyet, başarı, vb. gibi bilişsel ve psikolojik ihtiyaçlarının ortadan kaldırılması sonucunda denge durumunun sağlanmasıdır (Şimşek ve Büyükkıdık, 2015, s. 21). Yaşam doyumu ise, belirli bir durumdan memnuniyet değil, tüm yaşamdan memnuniyet anlamına gelir (Çelebi ve Çelebi, 2018, s. 6-7). Genel olarak kişinin tüm yaşamını ve bu yaşamın çeşitli yönlerini içerir (Deniz vd., 2012). Yaşam doyumunu etkileyen birçok faktör bulunmaktadır. Bunlar; fiziksel, sosyal, duygusal, zihinsel sağlık, psikolojik iyi olma hali, etkili ve işlevsel iletişim kurma, sosyal ilişkileri başlatma, sürdürme ve sosyal bağlantılara sahip olma gibi faktörlerdir (Kermen vd., 2016). Seligman’a (2007) göre, kişinin kendini mutlu hissetmesi pozitif duygulanıma, hayata bağlı olmaya ve hayatın anlamlı olduğunu düşünmesine bağlıdır. Bunların kendi içindeki düzeylerinin yüksek olması demek, yaşam doyumunun da yüksek olması anlamına gelmektedir. Yaşam doyumu ile çalışılan kavramlardan biriside benlik algısıdır. Yaşam doyumu ve benlik algısı arasında olumlu bir ilişki olduğu görülmektedir. Bu durum bizi, kişinin kendisi ve yaşamı ile ilgili değerlendirmelerinin birbirini etkilediği sonucuna götürmektedir (Akman, 2019, s. 45).

Bireylerin yaşam doyum düzeyi arttıkça, iyimserlik düzeyleri de artmaktadır (Avşaroğlu ve Koç, 2019, s. 567). Yaşam doyumu bir toplumda yaşam kalitesini belirleyen faktör olarak görülmektedir. Kültürlerarasi bir çalışmada, yaşam doyumunun fiziksel ve psikolojik sağlığın korunmasında, sahip olunan sosyal ilişkinin derecesi ile ilişkili olduğu bulunmuştur (Kermen vd., 2016, s. 22). Belirli bir dijital bağımlılık eşiği aşıldığında, yaşam memnuniyeti üzerinde daha olumsuz bir etki göstermesi beklenebilir (Lachmann vd., 2018, s. 2). Son yüzyılda beden imajı ile ilgili araştırmalar artmıstır. Bunun sebeplerinden biri, beden imajında olumsuz algıya sahip olmanın, bireyin yaşamının geri kalanını da olumsuz etkilemesidir. Birey dış görünüşü sebebi ile bir ortama girmekten çekinebilmektedir (Gülcan ve Bal, 2014, s. 47). Beden imgesi kişinin çevresine, kendi algııına göre şekillenebilmektedir. Bireyin görüntüsü ile ilgili algısı onun tepkilerini, duygularını etkilemektedir. Bununla beraber bireyin genel iyilik haline de etki edebilmektedir (Arslangiray, 2013, s. 3). İzgiş (2019, s. 32-36), öğretmenlerin algıladıkları sosyal desteğin artmasının yaşam doyumlarını da artırdığını, yine yaşam doyumu cinsiyet açısından incelendiğinde erkek öğretmenlerin, kadınlardan daha yüksek yaşam doyumuna sahip olduğunu ifade etmektedir. Ed Diener vd. (1985, s. 71) ise; yaşam doyumunun öznel iyi oluşun bilişsel boyutu ile ilişkili ve insanların kendileri için oluşturduğu standartlar ile ilgili olduğunu belirtmiştir (Kula ve Çakar, 2015, s. 193). Ayrıca yaşam doyumu, bireylerin belirledikleri 
standartlar ölçüsünde devam eden hayatlarını değerlendirip bir sonuca ulaşması, yani bireyin yaşamak istediği hayat ile sahip olduğu hayat arasında kıyaslama yapma durumu olarak ifade edilmektedir (Yıldız ve Baytemir, 2016, s. 69).

Çalışmada yaşam doyumu üzerine etkisi araştırlan olan kavramlardan biri de yalnızlıktır. Her bilim, insanın karanlık tarafını aydınlatmayı amaçlayan bir fener gibidir. Her araştırma, bilimsel anlamda her katkı, insanın çok boyutlu yapısının karanlık mahzenlerine ışık tutmaktadır. Yalnızlık, insanın karanlık tarafını simgeleyen, hayatı dayanılmaz kılan ve aydınlanmayı bekleyen modern dünyanın en önemli sorunlarından biridir (Baltac1, 2019, s. 74-75; Yakut ve Certel, 2016, s. 74-75). Çalışmalar incelendiğinde, insanların aslında iyi bir ilişki kurmak istedikleri, ancak bunu nasıl yapacaklarını bilmedikleri zaman, yalnızlık ve depresyon yaşadıkları bildirilmektedir (Uzuner ve Karagün, 2014, s. 109). Ağırman ve Gençer (2017, s. 235) yapmış oldukları bir çalışmada, yalnızlık ve depresyonun, artan kentleşme ve teknolojik gelişmelerle birlikte, insanların iletişiminin ve paylaşımlarının zayıflaması nedeniyle giderek daha fazla gözlenmektedir. Yalnızlık duygusunun öz sayg1, depresyon, anksiyete, kişilerarası düşmanlık, madde bağımlılı̆̆1, intihar ve sağlık sorunlarına yatkınlık, sosyal ağ, nevrotiklik ve sosyal kaygı, sosyal açıklık ve güvenli bağlanma, sosyal destek, mutsuzluk, mükemmeliyetçilik ve duygusal zekâ ile ilişkili olduğu görülmektedir (Feridun vd., 2018, s. 1795). Ayrıca çeşitli sosyo demografik karakterlerin yalnızlığı etkilediği de bilinmektedir. Bununla birlikte, bu demografik karakterlerin belirlenmesi ve anlaşılması, yaşı bireylerle yapılan çalışmalarda klinisyenlere ve araştırmacılara yol gösterecektir (Saltan ve Küçük, 2018, s. 192-193).

Ergenlik döneminde yaşanan yoğun bir duygu olan öfke, kontrol edilemezse bazı olumsuz deneyimlere yol açabilir. Yalnızlık bu olumsuz deneyimlerden biridir. Kontrol edilemeyen öfke sonucunda ergenler, kendileri için büyük öneme sahip olan arkadaşları tarafından dışlanabilir, arkadaşları ile ilişkilerinde yoğun öfke patlamaları yaşayabilirler (Haskan ve Yıldırım, 2014, s. 158). Buna paralel olarak, yalnızlık hisseden ergenlerin duygularını kolayca ifade edemedikleri (Baltacı, 2019, 74-75) ve öfke duygularını şiddetli bir eğilime dönüştürdükleri düşünülmektedir. Ergenlerin okulda yalnız kalmamaları, akranları tarafindan kabul edilmeleri önemlidir. Ergenler dünyasında, okul arkadaşları arasında iyi bir konuma, popülerliğe, liderliğe ve güce sahip olmak büyük anlamlara sahiptir. Zaman zaman, bu güç ve popülerliğe ulaşma ihtiyacı ergenleri şiddet içeren davranışlara yönlendirebilir. Şiddete eğilimli ergenlerin yüksek statüde olduğu, arkadaşları arasında popüler olduğu ve kabul edildiği görülmektedir (Hawley ve Vaugh, 2003, s. 240-241). Bireyin psikolojik sağlığını olumsuz etkileyen yalnızlığın, bireysel ve sosyal temeller üzerinde doğrudan veya dolaylı olumsuz etkileri mevcuttur. Ayrıca, ülkemizin geleceğinin şekillendiği eğitim kurumlarında, eğitim sürecinin en temel öğelerinden biri olan öğrencilerimizi de tehdit etmektedir. Çünkü yalnızlık, öğrencilerin psikolojik dünyalarını, hayata anlam katma bakış açılarını, iletişim kurma ve sosyalleşme yeteneklerini ve okul performanslarını olumsuz etkilediği için eğitimde, öğrenci başarısını da olumsuz etkilemektedir (Certel vd., 2016, s. 3072-3073).

Araştırmada ele alınan diğer bir kavram öz-tiksinmedir. Öz-tiksinme kavramını tanımlamak için öncelikle tiksinti kavramının açılanması gerekmektedir. Tiksinti, ilk olarak Darwin'den beri bilindiği düşünülen basit ve insani bir duygudur (Chapman ve Anderson, 2012, s. 62). Rozin ve Fallon (1987, s. 24) ise tiksinmeyi "Tiksindirici/Rahatsız edici bir nesnenin (sözlü) dâhil edilmesi ihtimaline karşı iğrenme" olarak tanımlamaktadır. İlgili literatür incelendiğinde, öz-tiksinmenin araştırmalarda, cinsel rahatsızlıklar, yeme bozuklukları ve sosyal anksiyete gibi ruh sağlı̆ı bozukluklarıyla birlikte çalışıldığı gözlemlenmiştir (Powell vd., 2014, s. 109). Tiksinmenin kendiliğe uyumsuz bir şekilde yönlendirilebileceği fikri, klinik psikoloji içinde ampirik kökenlere sahiptir ve benlik, beden ve kişinin eylemlerini, özellikle de sözde arzulanan benliği ihlal eden davranışlara vurgu yaparak aşırı nefret deneyimlerini içeren ayrı bir duygu olarak tanımlanmıştır (Moncrieff-Boyd, 2014, s. 8).

Öz-tiksinme, kişinin kendini düşük değerlendirmesinin bir sonucu olarak kendinden iğrenmesi hali olarak tanımlanmıştır (Johnson-Laird ve Oatley, 1989, s. 119). Powell vd. (2015a, s. 24) ise; öz-tiksinmeyi, 'kişinin vücudunun bazı kısımlarını iğrenç olarak değerlendirmesi ile kendini gösteren bir öz değerlendirme' olarak ifade etmektedir. Tiksinti, günlük hayatta insanı etkileyen önemli bir duygudur. Olumsuz sosyalleşmede önemli bir rol oynar ve çoğu zaman insanların tiksinti durumlarını deneyimlemekten veya düşünmekten kaçındığı gözlemlenmiştir (Rozin vd., 1999, s. 331).

İğrenme, sempatik büyülü düşünmeyle de yakından bağlantılıdır. İğrenç şeyler dokundukları şeyleri kirletir, sempatik büyülü bulaşma yasasına göre; "bir kez temasta olan, her zaman temastadır" anlayışı hakimdir (Haidt vd., 1994, s. 702; Rozin vd., 1999, s. 332-333). İğrenç şeylere verilen yanıtlar o kadar güçlüdür ki, iğrenme genellikle doğası gereği iğrenç olmayan, ancak iğrenç şeylere benzeyen varlıklara 
genelleme yapar (Rozin vd., 1986, s. 703). En yaygın tiksinti tetikleyicilerin birçoğu sempatik büyü yasalarından dolayı etkilidir. Örneğin, daha önce sevilmeyen bir kişi tarafından giyilmiş temiz kıyafetleri giymeye yönelik gösterilen tiksinti tepkisi, genelleme yapılarak davranış haline getirilebilir (Rozin vd., 1999, s. 333). Bu faktörlerin yanı sıra (yani, sosyal baskılar ve mide bulandırıcı/iğrenç deneyimler), yüksek tiksinme eğilimi, insanların kendi bedenlerine (örn. vücut yağı, akne) yönelik tiksinti yaşama ihtimalini artırabilir. Kişi kendi vücudunun itici olduğuna ilişkin, tekrar tekrar deneyim geçirdiğinde, kendine karşı bir öz-tiksinme alg1sı da geliştirebilir (Spreckelsen vd., 2018, s. 2). Bununla birlikte öz-tiksinmenin depresyon ve cinsel istismar ile de yakından ilişkili olduğu görülmektedir (Simpson vd., 2010, s. 61).

Utanç ve öz-tiksinme deneyiminin, özellikle yeme bozukluğu çekenlerde benzer olabileceği öne sürülmüştür (Fox vd., 2012, s. 238). Her ikisi de kaçınma ve itme veya sosyal reddetme duygularını içeren (Chapman vd., 2009, s. 1222) ve genellikle bir kişinin rahatsız edici durumlardan hızlı bir şekilde çekilmesine neden olan duygulardır. Bununla birlikte, bu iki duygu daha detaylı incelendiğinde, öztiksinme; utanç, suçluluk ve kendinden nefret etme gibi diğer olumsuz duygulardan, iğrenç olduğu düşünülen bir şeyle etkileşime girerken yaşanan benzersiz tiksinti duygusu sebebiyle farklıdır (Powell vd., 2015a, s. 5)

Öz-tiksinme iki faktörden oluşur: kendinden iğrenme ve davranışlarından iğrenme (Overton, Markland, Taggart vd., 2008, s. 381). Bu nedenle, bireyler kendilerinden tiksinti hissettiklerinde başka şeylerle meşgul olurlar ve gerginlik kendine zarar verme yoluyla hafifler. Öz-tiksinme, bireyin kendini eleştirel değerlendirmesinin bir yönünü içeren öz bilinçli bir duygudur. Dış ortama yönelik olmaktan ziyade öze yönelimli olması bakımından genel tiksinme duygularından farklıdır. Öz-tiksinme, şu iki bileşeni içerecek şekilde kavramsallaştırılan bir özeleştirme biçimi olarak öne sürülmüştür: öz-tiksinme; kendinden nefret etme ve kendini eleştirme (Smith vd., 2015, s. 62). Bu araştırma; yetişkinlerin yalnızlık ve öztiksinme düzeylerinin yaşam doyumunu ne düzeyde açıladığını ortaya koymak amacıyla yapılmıştır.

\section{Yöntem}

Araştırmada, yetişkinlerin yaşam doyumu, yalnızlık ve öz-tiksinme düzeyleri arasındaki ilişkinin incelenmesi amacıyla nicel araştırma yöntemlerinden ilişkisel tarama modeli kullanılmıştır.

\section{Evren - Örneklem}

Araştırmanın katılımcıları rastgele örnekleme yöntemiyle seçilmiştir. Toplanan veriler için değerlendirme kriteri 18 yaş ve üzeridir. Bu nedenle gerekli değerlendirme sonucunda bir kişi yaş kriterine uymadığ için çıkarılmış, araştırma 634 kişi ile yürütülmüştür. Katılımcıların 353’ü (\%56) kadın, 281’i (\%44) ise erkektir.

\section{Veri Toplama Araçları}

Bu araştırmada, verilerin elde edilmesinde "UCLA Yalnızlık Ölçeği kısa formu", "Yaşam Doyumu Ölçeği", "Öz-tiksinme Ölçeği” ve çalışmayı yürüten araştırmacılar tarafından geliştirilen "Kişisel Bilgi Formu" kullanılmıştır.

Kişisel Bilgi Formu: Kişisel bilgi formunda katılımcıların demografik bilgileri (yaş, cinsiyet, eğitim durumu, çalışma durumu, algilanan gelir düzeyleri ve medeni durum) yer almaktadır.

Yaşam Doyumu Ölçeği: Yaşam doyumu ile ilgili veri toplamak için Diener, Griffin, Larsen ve Emmons (1985) tarafından geliştirilen 5 maddeli 7’li likert tipi ölçek kullanılmıştır. Maddelerin her biri 1 ile 7 puan arasında puanlanmaktadır. Ölçeğin en düşük puanı 5 en yüksek puanı ise 35'tir.Ölçeğin güvenirlik çalısmaları sonucunda; test-tekrar test güvenirlik katsayısı .85 , madde-test korelasyonları ise .71 ile .80 arasında hesaplanmışır. Ölçekten alınan puanlar yükseldikçe, kişinin yaşamdan almış olduğu doyum artarken, alınan puanlar düştükçe yaşamdan elde edilen doyum azalmaktadır.

UCLA Yalnıそlık Ölçeği Kısa Formu: Yalnızlık ile ilgili veriler UCLA Yalnızlık Ölçeği (kısa form) ile toplanmıştır. Ölçek, Hay ve Dimatteo (1987) tarafindan UCLA Loneless Scale'den türetilmiştir. (Hay ve Dimatteo 1987 Akt: Doğan, Çötok ve Tekin, 2011). Doğan, Çötok ve Tekin (2011) tarafindan Türkçeye uyarlanmıştır. 8 maddesi bulunmaktadır. 2, 3, 7 ve 8 . Maddeler ters kodlanmaktadır. Ölçeğin iç tutarllı̆̆g ise.84'tür.Ölçekten alınan puanlar arttıkça bireylerin yalnızlık düzeyi artmakta, azaldıkça yalnızlık düzeyi azalmaktadır.

Öz-tiksinme Ölçeği: Öz-tiksinme ile ilgili veri toplamak için ise Bahtiyar ve Yıldırım (2019) tarafindan Türkçe’ye uyarlaması yapılan öz-tiksinme ölçeği kullanılmıstır. 21 maddeden oluşan öz-tiksinme ölçeğinin 
7'si dolgu maddesi olup, 9'u ise ters kodlanmaktadır. Maddeler 7'li likert tipinde olup dolgu maddeleri puanlamaya dahil edilmemektedir. Ölçeğin iç tutarlığ .91 ve test tekrar test güvenilirliği 94 bulunmuştur. Ölçekten alınan puanın artması, öz-tiksinmeye işaret etmektedir.

\section{Verilerin Analizi}

Araştırma verileri 2019 yllı içerisinde, Google Forms üzerinden toplanmış olup analizi için SPSS 22.00 paket programı kullanılmıştır. Yalnızlık ve öz-tiksinmenin yaşam doyumunu ne derecede yordadığını bulmak için çoklu regresyon analizi kullanılmıştır. Ayrıca yaşam doyumu, öz-tiksinme ve yalnızlık düzeylerinin cinsiyete, medeni duruma ve çalşsma durumuna göre anlamlı bir şekilde farklılaşıp farklılaşmadığını test etmek için, Bağımsız Gruplar T testi, Mann Whitney U testi; eğitim durumu ve gelir düzeyine göre farklılaşma olup olmadığını test etmek için ise Anova ve Kruskal Wallis kullanılmıştır.

\section{Bulgular}

Araştırmanın bu kısmında, belirlenen amaç doğrultusunda analizler sırasına göre yapılmıştır.

Tablo 1. Değğskenlere Iliş̧kin Betimleyici Istatistikler

\begin{tabular}{lcccccc}
\hline & $\mathbf{n}$ & Ranj & Minimum & Maksimum & Ortalama & $\begin{array}{c}\text { Standart } \\
\text { Sapma }\end{array}$ \\
\hline Yaşam Doyumu & 634 & 20.00 & 5.00 & 25.00 & 16.73 & 4.04 \\
Yalnızlik & 634 & 24.00 & 8.00 & 32.00 & 25.66 & 4.58 \\
Öz-tiksinme & 634 & 72.00 & 20.00 & 92.00 & 39.88 & 17.18 \\
\hline
\end{tabular}

Tablo 1 incelendiğinde, 634 kişinin yaşam doyumu ölçeğinden aldığ1 en yüksek puan 25, en düşük puan 5 iken; yaşam doyumu ortalaması 16,73 olarak görülmektedir. Yalnızlık ölçeğinde ise, minimum 8, maksimum 32 puan alınırken, ortalamanın 25,66 olduğu görülmektedir. Grupta öz-tiksinme ölçeğinden elde edilen puanlarda minimum 20 maksimum ise 92 puan alınırken ortalama 39,88 olarak bulunmuştur.

Tablo 2. Yalnı̨lık ve Öz-tikesinmenin Yaşam Doyumunu Açılamasına Yönelik Cokelu Regresyon Analiz̧i Sonucları

\begin{tabular}{ccccccccccc}
\hline $\begin{array}{c}\text { Yordanan } \\
\text { Değişken }\end{array}$ & $\begin{array}{c}\text { Yordayıc1 } \\
\text { Değişkenler }\end{array}$ & $\mathbf{B}$ & $\mathbf{B}$ & $\mathbf{t}$ & $\mathbf{p}$ & $\mathbf{R}$ & $\mathbf{R}^{2}$ & $\boldsymbol{\Delta} \mathbf{R}^{2}$ & $\mathbf{F}$ & $\mathbf{S D}$ \\
\hline $\begin{array}{c}\text { Yaşam } \\
\text { Doyumu }\end{array}$ & Yalnızlık & 0.293 & 0.33 & 8.81 & $\mathbf{0 . 0 0 *}$ & 0.37 & 0.139 & 0.136 & 50.85 & 2 \\
\cline { 2 - 10 } & Öz-tiksinme & -0.028 & -0.11 & -3.14 & $\mathbf{0 . 0 0 *}$ & & & & & \\
\hline
\end{tabular}

$p<.05 *$

Araştırma, yalnızlık ve öz-tiksinmenin yaşam doyumunun bir yordayıcısı olup olmadığını belirlemek için yapılmıştır. Çoklu doğrusal regresyon analizinin varsayımları test edilmiş olup, analiz sonucunda bütün varsayımları karşıladığ1 gözlenmiştir. Durbin-Watson $(2,011)$ puanına bakıldığında verilerin arasında otokorelasyon olmadığ1 görülmektedir. Yani gözlemlerin birbirinden bağımsız olduğu varsayımı karşılanmıştır. Varyans büyütme faktörü (VIF) değeri 1.03 ve tolerans değeri 0,96 olarak bulunmuştur. Ölçüt alınabilecek olan bu değerler, analizin çoklu bağıntı problemine sahip olmadığını göstermektedir. Her bir bağımsız değişken arasında doğrusal bir ilişki olduğu gözlenmiştir Casewise Diagnostic tablosunun değerlerine bakıldığında uç değerler görülmemektedir. Atıklar ise normal olarak dağılmaktadır. Yalnızlık ve öz-tiksinmenin yaşam doyumu üzerindeki etkisinin anlamlı olduğu ortaya çıkmıştır. $F(2,50), p<.05, R 2=$ .13 , adj. $R 2=.13 \mathrm{Bu}$ sonuç yalnızlık ve öz-tiksinmenin yaşam doyumunda toplam varyansın \%13' ünü açıkladığı göstermektedir. Standardize edilmiş regresyon katsayısına göre $(\beta)$, yordayıcı değişkenlerin, yaşam doyumu üzerindeki önem sırası; yanlızlık $(\beta=.29, p<.05)$ ve öz-tiksinme $(\beta=-0,11, p<.05)$ şeklinde olduğu görülmektedir.

Tablo 3. Yaşam Doyumu, Yalnı̨lık ve Öz-tiksinme Arasındaki İlişki

\begin{tabular}{lccc}
\hline & Yaşam doyumu & Yalnızlık & Öz-tiksinme \\
\hline Yaşam Doyumu & 1 & & 1 \\
Yalnızlık & $0.35^{*}$ & $-0.18^{*}$ & 1 \\
Öz-tiksinme & $-0.18^{*}$ & 1 \\
\hline
\end{tabular}


Tablo 3'te ise katılımcıların yaşam doyumu, yalnızlık ve öz-tiksinme düzeyleri arasındaki korelasyon sonuçlarına yer verilmiştir. Yaşam doyumu ile yalnızlık arasında $(\mathrm{r}=0,35, p<.05)$ pozitif düşük düzey anlamlı bir ilişki görülmektedir. Yalnızlık arttıkça yaşam doyumu da artmaktadır. Tablodan hareketle yaşam doyumu ve öz-tiksinme arasında $(r=-0,18, p<.05)$ düşük düzey ters yönlü ilişki söz konusudur. Buradan hareketle öz-tiksinme düzeyi arttıkça yaşam doyumunun düştüğünü söylemek mümkündür. Yine tabloda görüldüğü üzere öz-tiksinme ve yalnızlık arasında $\mathrm{da}(\mathrm{r}=-0,18, p<.05)$ ters yönlü düşük düzey ilişki vardır. Öz tiksinti düzeyi arttıkça yalnızlık azalmakta, yalnızlık azaldıkça da öz-tiksinme artmaktadır.

Tablo 4. Yaşam Doyumunun Cinsiyete Göre t Testi Sonuclar

\begin{tabular}{llccccc}
\hline & Cinsiyet & $\mathbf{n}$ & Ortalama & $\begin{array}{c}\text { Standart } \\
\text { sapma }\end{array}$ & $\mathbf{t}$ & $\mathbf{p}$ \\
\hline Yaşam & Kadın & 353 & 16.41 & 3.86 & -2.241 & $\mathbf{0 . 0 2}^{*}$ \\
Doyumu & Erkek & 281 & 17.14 & 4.24 & & \\
\hline
\end{tabular}
$p<.05^{*}$

Araştırmada katılımcıların cinsiyetlerine göre yaşam doyumlarının farklılaşıp farklılaşmadığını test etmek üzere bağımsız örneklemler t-testi kullanılmıştır. t-testinin kullanılabilir olup olmadığını test etmek için, test varsayımlarına bakılmıştır. İlk olarak yaşam doyumu için, normallik ile uç değerlerin mevcut olup olmadığ1 kontrol edilmiştir. Histogram grafiği incelendiğinde, grubun yaklaşık olarak normal bir şekilde dağıldığ1 gözlenmiştir. Dolayısı ile veri üzerinde herhangi bir değişiklik yapılmadan (ör; veri transformation) ya da parametrik olmayan bir alternatif test kullanmadan (Mann-Whitney U Testi), veri olduğu şekliyle kullanılmıştır. Levene's Eşit Varyanslar Testi, anlamlı bir $p$ değeri vermediği için, varyansların homojenliği söz konusudur. Dolayısı ile, bağımsız örneklemler t-testi sonuçları için, varyansların eşit olduğu seçenek göz önüne alınmıştır. Grup verileri incelendiğinde, kadınların yaşam doyumu ölçeğinden aldığ1 puanlar ortalama 16,41 iken $(n=353$; $S S=3,86)$, erkeklerin yaşam doyumu ölçeğinden aldığı puanlar ortalama 17,14'tür $(n=281 S S=4,24)$. Buradan hareketle erkeklerin yaşam doyumunun kadınlardan anlamlı düzeyde farklılaştığını söyleyebiliriz.

Tablo 5. Yalnı̨lı ve Öz-tiksinme Cinsiyete Göre Mann Whitney U Testi Sonuclar

\begin{tabular}{|c|c|c|c|c|c|c|}
\hline & Cinsiyet & $\mathbf{n}$ & $\begin{array}{c}\text { Siralama } \\
\text { Ortalaması }\end{array}$ & $\begin{array}{l}\text { Siralama } \\
\text { Toplamı }\end{array}$ & $\mathbf{U}$ & $\mathrm{p}$ \\
\hline \multirow{2}{*}{ Yalnızlık } & Kadin & 353 & 316.06 & 111567.50 & 49086.50 & 0.823 \\
\hline & Erkek & 281 & 319.31 & 89727.50 & & \\
\hline \multirow{2}{*}{ Öz-tiksinme } & Kadın & 353 & 292.41 & 103220.00 & 40739.00 & $0.00 *$ \\
\hline & Erkek & 281 & 349.02 & 98075.00 & & \\
\hline
\end{tabular}

$p<.05 *$

Araştırmada katılımcıların cinsiyete göre yalnızlık ve öz-tiksinme düzeyleri normallik varsayımını karşılamadığ1 ve box plotlardaki uç değerlerin varllğ̣ sebebi ile t-testinin non-parametrik karşllğı olan Mann Whitney U testi kullanılmıştır. Mann Whitney U testi sonuçları, yukarıda Tablo 5'te görüldüğü üzere, yalnızlı ölçeğinden elde edilen puanlar cinsiyete göre anlamlı farklılık göstermemektedir (U $=49086,50, \mathrm{p}>$.05). Ancak öz-tiksinme düzeyleri cinsiyete göre farklılaşmaktadır. $(\mathrm{U}=40739,00, \mathrm{p}<.05)$ Tablodan hareketle erkeklerin öz-tiksinme düzeyinin kadınlardan anlamlı düzeyde farklılaşttğı görülmektedir. Erkeklerin öz-tiksinme sıralama ortalamaları $(349,02)$ kadınlardan $(292,41)$ fazladır.

Tablo 6. Yașam Doyumunun Medeni Duruma Göre t Testi Sonucları

\begin{tabular}{llllllll}
\hline & $\begin{array}{l}\text { Medeni } \\
\text { Durum }\end{array}$ & $\mathbf{n}$ & Ortalama & $\begin{array}{l}\text { Standart } \\
\text { Sapma }\end{array}$ & SD & t & p \\
\hline Yaşam & Evli & 306 & 17.21 & 4.11 & 632 & 2.875 & $\mathbf{0 . 0 4 *}$ \\
Doyumu & Bekâr & 328 & 16.29 & 3.94 & & & \\
\hline
\end{tabular}

$p<.05 *$

Araştırmada katılımcıların medeni durumuna göre yaşam doyumunun farklılaşıp farklılaşmadığı test edilmek üzere bağımsız örneklemler $\mathrm{t}$-testi kullanılmıştır. $\mathrm{t}$-testinin kullanılabilir olup olmadığını test etmek için, test varsayımlarına bakılmıştır. İlk olarak, yaşam doyumu için normallik ile uç değerlerin mevcut olup olmadığ1 kontrol edilmiştir. Histogram grafiği incelendiğinde, grubun yaklaşık olarak normal bir şekilde dağıldığı gözlenmiştir. Dolayısı ile veri üzerinde herhangi bir değişiklik yapılmadan (ör; veri transformation) ya da parametrik olmayan bir alternatif test kullanılmadan (Mann-Whitney U Testi), veri 
olduğu şekliyle kullanılmıştır. Levene's Eşit Varyanslar Testi, anlamlı bir p değeri vermediği için, varyansların homojenliği söz konusudur. Dolayısı ile bağımsız örneklemler t-testi sonuçları için, varyansların eşit olduğu seçenek göz önüne alınmıştır. Grup verileri incelendiğinde, evlilerin yaşam doyumu ölçeğinden aldığ1 puanlar ortalama 17,21 iken $(n=306 ; S S=4,11)$, bekârların yaşam doyumu ölçeğinden aldığ1 puanlar ortalama 16,29 'dur $(n=328 ; S S=3,94)$. Buradan hareketle medeni durum baz alındığında evlilerin yaşam doyumunun bekarlardan anlamlı düzeyde farklılaştığını söyleyebiliriz.

Tablo 7. Yalnųllkeve Öz-tiksinme Medeni Duruma Göre Mann Whitney U Testi Sonuclar

\begin{tabular}{llccccc}
\hline & Medeni Durum & $\mathbf{n}$ & $\begin{array}{c}\text { Siralama } \\
\text { Ortalamasi }\end{array}$ & $\begin{array}{c}\text { Siralama } \\
\text { Toplami }\end{array}$ & $\mathbf{u}$ \\
\hline \multirow{2}{*}{ Yalnızlık } & Evli & 306 & 318.67 & 97512.50 & 49826.500 \\
& Bekâr & 328 & 316.41 & 103782.50 & 0.876 \\
\hline \multirow{2}{*}{ Öz-tiksinme } & Evli & 306 & 319.32 & 97712.00 & 49627.000 \\
& Bekâr & 328 & 315.80 & 103583.00 & \\
\hline
\end{tabular}

$p<.05 *$

Araştırmada katılımcıların medeni durumlarına göre, yalnızlık ve öz-tiksinme düzeyleri normallik varsayımını karşılamadığ ve box plotlardaki uç değerlerin varlığ1 sebebi ile t-testinin non-parametrik karşıllğı olan Mann Whitney U testi kullanılmışıtır. Mann whitney u testi sonuçları, yukarıda Tablo 7 'de görüldüğü üzere, yalnızlık ölçeğinden elde edilen puanlar medeni duruma göre anlamlı farklılık göstermemektedir. ( $\mathrm{U}=49826,500, \mathrm{p}>$.05). Öz-tiksinme düzeyleri de medeni duruma göre anlamlı farkll11k göstermemektedir. $(\mathrm{U}=40739,00, \mathrm{p}<.05)$.

Tablo 8. Yaşam Doyumu Callşma Durumuna Göre t Testi Sonuclar

\begin{tabular}{|c|c|c|c|c|c|c|c|}
\hline & $\begin{array}{l}\text { Çalışma } \\
\text { Durumu }\end{array}$ & $\mathrm{n}$ & Ortalama & $\begin{array}{l}\text { Standart } \\
\text { Sapma }\end{array}$ & SD & $\mathbf{t}$ & $\mathrm{p}$ \\
\hline Yaşam & Çalışı̀or & 377 & 17.09 & 3.80 & 632 & 2.67 & $0.00 *$ \\
\hline Doyumu & Çalışmıyor & 257 & 16.22 & 4.33 & & & \\
\hline
\end{tabular}

$p<.05 *$

Araştırmada katılımcıların çalışma durumlarına göre yaşam doyumunun farklılaşıp farklılaşmadığı test edilmek üzere bağımsız örneklemler t-testi kullanılmıştır. t-testinin kullanılabilir olup olmadığını test etmek için, test varsayımlarına bakılmıştır. İlk olarak, yaşam doyumu için normallik ile uç değerler kontrol edilmiştir. Histogram grafiği incelendiğinde, grubun yaklaşık olarak normal bir şekilde dağıldığı gözlenmiştir. Dolayısı ile veri üzerinde herhangi bir değişiklik yapılmadan (ör; veri transformation) ya da parametrik olmayan bir alternatif test kullanılmadan (Mann-Whitney U Testi), işlem gerçekleştirilmiştir. Levene's Eşit Varyanslar Testi, anlamlı bir p değeri vermediği için, varyansların homojenliği söz konusudur. Dolayısı ile bağımsız örneklemler t-testi sonuçları için, varyansların eşit olduğu seçenek göz önüne alınmıştır. Tablo 8'de ifade edildiği şekilde, iş sahibi olanlar ile olmayanlar arasında anlamlı bir farklılık mevcuttur. Çalışanların yaşam doyumu ölçeğinden aldığı puanlar ortalama 17,09 iken $(n=377 ; S S$ $=3,80)$, çalışmayanların yaşam doyumu ölçeğinden aldığı puan ortalamaları 16,22' $\operatorname{dir}(n=328 ; S S=4,33)$.

Tablo 9. Yalnı‡llk ve Öz-tiksinme Calısma Durumuna Göre Mann Whitney U Testi Sonuclar

\begin{tabular}{|c|c|c|c|c|c|c|}
\hline & $\begin{array}{l}\text { Çalışma } \\
\text { Durumu } \\
\end{array}$ & $\mathrm{n}$ & $\begin{array}{c}\text { Siralama } \\
\text { Ortalamas1 } \\
\end{array}$ & $\begin{array}{l}\text { Siralama } \\
\text { Toplamı } \\
\end{array}$ & $\mathbf{U}$ & $\mathrm{p}$ \\
\hline \multirow{2}{*}{ Öz-tiksinme } & Çalışıyor & 377 & 322.86 & 121720.00 & 46422.00 & 0.371 \\
\hline & Çalışmiyor & 257 & 309.63 & 79575.00 & & \\
\hline \multirow{2}{*}{ Yalnızlık } & Çalışıyor & 377 & 328.23 & 123741.00 & 44401.00 & 0.073 \\
\hline & Çalıșmıyor & 257 & 301.77 & 77554.00 & & \\
\hline
\end{tabular}

$p<.05^{*}$

Araştırmada katılımcıların çalışma durumlarına göre yalnızlık ve öz-tiksinme düzeyleri, normallik varsayımını karşılamadığı ve box plotlardaki uç değerlerin varllğ1 sebebi ile t-testinin non-parametrik karşıllğı olan Mann Whitney $U$ testi kullanılmıştır. Mann Whitney u testi sonuçlarına göre, öz-tiksinme düzeyleri medeni duruma göre anlamlı farklllık göstermemektedir. $(\mathrm{U}=46422,00, \mathrm{p}>.05)$ Bununla beraber yalnızlık ölçeğinden elde edilen puanlarda medeni duruma göre anlamlı bir farklılık göstermemektedir. (U $=44401,00, \mathrm{p}>.05)$. 
Tablo 10. Yaşam Doyumunun Gelir Düzeyine Göre Anova Sonuclar

\begin{tabular}{llccccccc}
\hline & Gelir & $\mathbf{n}$ & $\mathbf{X}$ & SS & SD & F & p & Anlamli Fark \\
\hline \multirow{2}{*}{ Yaşam } & Düzsük & 65 & 13.72 & 4.38 & 2 & 27.88 & $\mathbf{0 . 0 0 *}$ & Düşük-Orta \\
Doyumu & Orta & 513 & 16.89 & 3.94 & & & Orta-Yüksek \\
& Yüksek & 56 & 18.80 & 3.65 & & & & Düşük-Yüksek \\
\hline
\end{tabular}

$p<.05 *$

Yaşam doyumunun, gelir düzeyine göre değișip değișmediğini test etmek için tek yönlü ANOVA analizi yapılmıştır. Analizde, gelir durumu üç gruba ayrılmıştır: düşük düzey $(n=65)$, orta düzey $(n=513)$ ve yüksek düzey $(n=56)$ daha ayrıntılı bilgi için Tablo 10’a bakınız. Box plot analizine göre, herhangi bir uç veri mevcut değildi ve gruplar normal olarak dağılmıştı. Varyansların eşit olup olmadığını anlamak için, Levene's test of homogeneity of variances $(p=0,26)$ incelenmiş ve $\mathrm{p}$ değeri istatistiksel olarak anlamlı olmadığ1 için varyansların homojenliği varsayımı karşılanmıştır. ANOVA testi, yaşam doyumunun gelir düzeyleri arasında anlamlı farklılıklar gösterdiğini ortaya çıkarmıstır, $F(2,631)=27,88, p<.05$ Yaşam doyumu gelir düzeyine göre incelendiğinde, düşük düzeyde $(X=13,72, S S=4,38)$, orta düzeyde $(X=$ $16,89, S S=3,94)$ ve yüksek düzeyde $(X=18,80, S S=3,65)$ şeklinde görülmektedir. Tukey post hoc analizine göre, yaşam doyumu için, gruplar arasında anlamlı bir fark olduğu ve düşük düzeyden yüksek düzeye doğru yaşam doyumunda artış olduğu ortaya çıkarılmıştır.

Tablo 11. Yalmı̨lı ve Öz-tiksinmenin Gelir Düzeyine Göre Kruskal Wallis Sonuclarn

\begin{tabular}{llcccccc}
\hline & Gelir Düzeyi & $\mathbf{n}$ & Sira Ortalaması & SD & $\mathbf{X}^{2}$ & $\mathbf{p}$ & Anlaml1 Fark \\
\hline \multirow{3}{*}{ Yalnızlık } & Düşük & 65 & 232.71 & 2 & 18.51 & $\mathbf{0 . 0 0 *}$ & Düşük-Orta \\
& Orta & 513 & 322.88 & & & & Orta-Yüksek \\
& Yüksek & 56 & 366.64 & & & & Düşük-Yüksek \\
\hline \multirow{3}{*}{ Öz-tiksinme } & Düşük & 65 & 359.09 & 2 & 3.740 & 0.154 & - \\
& Orta & 513 & 312.85 & & & & \\
& Yüksek & 56 & 311.83 & & & & \\
\hline
\end{tabular}

$p<.05 *$

Yalnızlık ve öz-tiksinmenin, gelir düzeylerine göre değişip değişmediğini test etmek için varsayımlar kontrol edilmiştir. Boxplot analizine göre uç değerlerin varllğı ve gruplar normal olarak dağılmadığı için Kruskal Wallis analizi yapılmıştır. Kruskal Wallis sonucuna göre katılımcıların yalnızlık düzeylerinin gruplar arasında anlamlı farkllıklar gösterdiği ortaya çıkmıştır. $\left[\chi^{2}(\mathrm{sd}=2, \mathrm{n}=634)=18,51 p<.05\right.$ Games Howell analizine göre gelir düzeyi arttıkça yalnızlığında arttığı ortaya çıkmıştır. Öte yandan öz-tiksinme için, gruplar arasında anlamlı bir fark ortaya çımamıştır. $\left[\chi^{2}(\mathrm{sd}=2, \mathrm{n}=634)=3,740\right.$.

Tablo12. Yaşam Doyumunun Eğitim Durumlarna Göre Anova Sonuçar

\begin{tabular}{|c|c|c|c|c|c|c|c|c|}
\hline & Eğitim Durumu & $\mathbf{n}$ & $\mathbf{X}$ & SS & Sd & $\mathbf{F}$ & $\mathrm{p}$ & $\begin{array}{c}\text { Anlamli } \\
\text { fark }\end{array}$ \\
\hline \multirow{6}{*}{$\begin{array}{l}\text { Yaşam } \\
\text { Doyumu }\end{array}$} & İlkokul mezunu & 6 & 16.83 & 7.49 & \multirow[t]{6}{*}{5} & \multirow[t]{6}{*}{2.849} & \multirow[t]{6}{*}{$0.01 *$} & \multirow{6}{*}{$\begin{array}{c}\text { Ön lisans } \\
\text { mezunu } \\
\text { lisansüstü } \\
\text { mezunu }\end{array}$} \\
\hline & Ortaokul mezunu & 6 & 16.16 & 5.41 & & & & \\
\hline & Lise mezunu & 77 & 16.09 & 3.99 & & & & \\
\hline & Ön lisans mezunu & 34 & 15.02 & 4.34 & & & & \\
\hline & Lisans mezunu & 331 & 16.67 & 3.96 & & & & \\
\hline & Lisansüstü mezunu & 180 & 16.73 & 3.87 & & & & \\
\hline
\end{tabular}

$\overline{p<.05^{*}}$

Yaşam doyumunun eğitim düzeyine göre değişip değişmediğini test etmek için tek yönlü Anova analizi yapılmıştır. Analizde, eğitim düzeyi altı gruba ayrılmıştır: ilkokul mezunu $(n=6)$, ortaokul mezunu $(n=6)$, lise mezunu $(n=77)$, ön lisans mezunu $(n=34)$, lisans mezunu $(n=331)$, lisansüstü mezunu $(n=$ 180). Herhangi bir uç değer yoktur ve normallik varsayımı karşılanmıştır. Varyansların eşit olup olmadığını anlamak için Levene's test of homogeneity of variances $(p=1,56)$ incelenmiş ve p değeri istatistiksel olarak anlamlı olmadığı için varyansların homojenliği varsayımı karşılanmıştır. Anova testi, yaşam doyumunun eğitim düzeyleri arasında anlamlı farklılıklar gösterdiğini ortaya çıkarmıştır. $F(5,628)=2,84, p<.05$ Yaşam doyumu eğitim düzeyine göre incelendiğinde, ilkokul mezunu ( $X=16,83, S S=7,49)$, ortaokul mezunu ( $X=16,16 S S=35,41)$, lise mezunu $(X=16,09, S S=3,99)$, ön lisans mezunu $(X=15,02 S S=$ $4,34)$, lisans mezunu $(X=16,67 S S=3,96)$ ve lisansüstü mezunu $(X=16,73 S S=3,87)$ olduğu 
görülmektedir. Tukey post hoc analizine göre yaşam doyumu için, ön lisans mezunları ile lisansüstü mezunları arasında anlamlı bir fark vardır.

Tablo13. Yalnı̨llk ve Öz-tiksinmenin Eğitim Durumlarna Göre Kruskal Wallis Sonuclar

\begin{tabular}{|c|c|c|c|c|c|c|c|}
\hline & Gelir Düzeyi & $\mathbf{n}$ & Sira Ortalamas1 & SD & $\mathrm{X}^{2}$ & $\mathrm{p}$ & Anlamlı Fark \\
\hline \multirow{6}{*}{ Yalnızlık } & İlkokul mezunu & 6 & 123.25 & 5 & 21.247 & $0.00 *$ & \multirow{6}{*}{$\begin{array}{c}\text { Lisans } \\
\text { Mezunu-Ön } \\
\text { lisans Mezunu } \\
\text { Lisansüstü } \\
\text { mezunu-Ön } \\
\text { lisans Mezunu }\end{array}$} \\
\hline & Ortaokul mezunu & 6 & 251.58 & & & & \\
\hline & Lise mezunu & 77 & 300.21 & & & & \\
\hline & Ön lisans mezunu & 34 & 215.79 & & & & \\
\hline & Lisans mezunu & 331 & 326.63 & & & & \\
\hline & Lisansüstü mezunu & 180 & 335.88 & & & & \\
\hline \multirow{6}{*}{$\begin{array}{l}\text { Öz- } \\
\text { tiksinme }\end{array}$} & İlkokul mezunu & 6 & 282.92 & \multirow[t]{6}{*}{5} & \multirow[t]{6}{*}{1.117} & 0.953 & \multirow[t]{6}{*}{-} \\
\hline & Ortaokul mezunu & 6 & 318.67 & & & & \\
\hline & Lise mezunu & 77 & 309.36 & & & & \\
\hline & Ön lisans mezunu & 34 & 299.36 & & & & \\
\hline & Lisans mezunu & 331 & 323.65 & & & & \\
\hline & Lisansüstü mezunu & 180 & 314,11 & & & & \\
\hline
\end{tabular}

$p<.05^{*}$

Yalnızlık ve öz-tiksinmenin, eğitim düzeylerine göre değişip değişmediğini test etmek için varsayımlar kontrol edilmiştir. Boxplot analizine göre uç değerlerin varlığı ve gruplar normal olarak dağılmadığı için Anova yerine Kruskal Wallis analizi yapılmışır. Kruskal Wallis sonucuna göre, katılımcıların yalnızlık düzeylerinin gruplar arasında anlamlı farklılıklar gösterdiği ortaya çıkmıştır., $\left[\chi^{2}(S D=5, N=634)=21,247\right.$ $p<.05]$ Games Howell analizine göre, ön lisans mezunlarının yalnızlık düzeyleri hem lisans hem de lisansüstü mezunlarının yalnızlık düzeylerinden anlamlı olarak farklılaşmaktadır. Öte yandan öz-tiksinme için gruplar arasında anlamlı bir fark ortaya çıkmamıştır $\left[\chi^{2}(\mathrm{SD}=5, \mathrm{~N}=634)=1,117 p>.05\right]$.

\section{Tartışma, Sonuç ve Öneriler}

$\mathrm{Bu}$ araştırmada, yetişkinlerin yalnızlık ve öz-tiksinme düzeylerinin, yaşam doyumları üzerindeki yordayıcı gücü çeşitli değişkenler açısından ele alınmıştır. Elde edilen sonuçlara göre, yetişkinlerin yalnızlık ve öz-tiksinme düzeyleri, yaşam doyumlarının önemli yordayıcıları olarak bulunmuştur. Alan yazın incelendiğinde, yaşam doyumu, yalnızlık ve öz-tiksinme arasındaki ilişkiyi ortaya koyan herhangi bir çalışma olmamakla birlikte; bu makalenin, yaşam doyumu ve öz-tiksinme arasındaki ilişkiyi açıklayan ilk makale olması yönüyle önemli olduğu düşünülmektedir. Aşağıda araştırmadan elde edilen bulguların literatür ışı̆̆ında değerlendirilmesi yapılacaktır.

Araştırmada, yetişkin bireylerin yaşam doyumlarının cinsiyete göre farklılaştı̆̆ sonucu elde edilmiştir. Elde edilen araştırma sonuçlarına göre, erkeklerin yaşam doyumu kadınlardan daha yüksek bulunmuştur. Ancak, araştırma bulgularının çoğu (Yılmaz ve Arslan, 2013, s. 63; Dost, 2007, s. 138; Yıldız, 2016, s. 467; İncekara, 2018, s. 53) bu durumun tersine işaret etmektedir. Aynı zamanda cinsiyetin, yaşam doyumu üzerinde farklılık oluşturmadığını saptayan araştırmalar da vardır (Karaköse, 2019, s. 43). Yani, cinsiyet değişkeninin yaşam doyumu üzerindeki etkisi değişkenlik göstermektedir. Bu durum farklı araştırma gruplarındaki yapının, literatürde farklı sonuçlar doğurması nedeniyle olabilir. Ancak, kadınlardan beklenen roller ve kadınların toplumdaki refah durumları göz önüne alındığında, araştırma sonucunun bu yönde olması da şaşırtıcı gelmemektedir.

$\mathrm{Bu}$ araştırmada, yetişkin bireylerin yaşam doyumlarının medeni duruma göre farklılaştığı sonucu elde edilmiştir. Elde edilen bulgular, evli bireylerin yaşam doyumunun bekâr bireylere göre anlaml derecede daha yüksek olduğunu ortaya koymuştur. Bu bulgu literatürle paralellik göstermektedir (Demirel, 2018, s. 32-33; Ünal vd., 2001, s. 116-117). Evlilik bireylerin özel ve derin ilişkiler kurmasını sağlar ve bireyler hayatın zorluklarını eşleriyle birlikte aşarlar (Erdinç, 2018, s. 45). Yani, evliliğin hem kaliteli yakın ilişki hem de sosyal destek sağladığı düşünüldügünde evli bireylerin daha yüksek yaşam doyumuna sahip olması anlaşılabilir.

Araştırma bulguları, yaşam doyumu ve gelir düzeyi açısından incelendiğinde, yaşam doyumu ve gelir düzeyi arasında anlamlı bir ilişkinin olduğunu göstermektedir. Yaşam doyumu, düşük, orta ve yüksek gelir düzeyine sahip olmakla paralel bir şekilde artış göstermiştir. Yani gelir düzeyinin artsşı yaşam doyumunu da artırmıştır. Bu bulgu, Chow (2005, s. 105-106), İncekara (2018, s. 55), Dost’un (2007, s. 139-140) araştırma 
sonuçlarını desteklemektedir. Dost’a göre, ekonomik durum, insanın temel ihtiyaçlarını karşılamasından, kendini geliştirecek etkinlik ve faaliyetlere katıllım göstermesine kadar her türlü hedef için bir gerekliliktir (s. 140). Ayrıca, Staudinger, Fleeson ve Baltes (1999) de, sosyo-ekonomik durumun yaş ve cinsiyete kiyasla, öznel iyi oluşu nispeten daha güçlü yordayabileceğini söylemişlerdir (s. 306). Her ne kadar paranın mutluluk getirmeyeceği düşünülse de, bireylerin refahını sağlayacak belli bir miktar gelirin, yaşam doyumunu olumlu etkileyeceği düşünülmektedir (Stewart, 1976, s. 106). Nitekim, bütün bunlar bulgularımızla tutarlılık göstermektedir.

Araştırmada, ekonomik refah ile ilişkili olarak, çalışma durumunun da yaşam doyumunu farklılaştırdığı bulunmuştur. Elde edilen bulgulara göre, çalışanların yaşam doyumları çalışmayanlara göre anlamlı bir şekilde daha yüksektir. Ekonomik bağımsızlı̆ı kazanmış olma, yüksek yaşam doyumu ile ilişkilendirilmiştir (Hosseinkhanzadeh ve Taher, 2013, s. 99). Ayrıca işsizliğin bireyler üzerinde oluşturduğu stres ve ekonomik refahın yukarıda belirtilen olumlu etkisi düşünüldügünde de, bu beklenen bir sonuçtur. Aynı zamanda, kişinin çalışma hayatından elde ettiği doyum ve yaşam doyumu da karşlıklı olarak birbirini etkilemektedir (Keser, 2005, s. 897-911).

Araştırmada katılımcıların yaşam doyumu üzerinde etkisini gösteren bir başka değişken ise, eğitim durumudur. Elde edilen bulgulara göre lisansüstü mezunlarının yaşam doyumu, ön lisans mezunlarından daha yüksek bulunmuştur. Eğitim düzeyinin artması, bireye daha iyi iş olanakları, daha iyi bir gelir ve daha iyi sağlık şartları sağlar ve kişiyi daha üretken kılar (İzgiş, 2019, s. 13). Ayrıca, eğitimli insanların aile yaşamlarında becerilerini daha etkin kullandıkları ve isteklerini karşılamada daha başarılı oldukları düşünülmektedir (Karaköse, 2019, s. 20). Bütün bunlar, eğitim durumunun yaşam doyumu üzerindeki olumlu etkisini açıklar niteliktedir.

Araştırma sonuçları yalnızlık bağlamında ele alındığında, yalnızlık ile cinsiyet arasında anlamlı bir ilişki bulunmadığı görülmüştür. Literatür incelendiğinde, cinsiyete göre yalnızlık düzeylerinin farklılaşıp farklılaşmadığı noktasında çelişkili bulgular olduğu görülmektedir. Ancak, araştırma bulgusu Çeçen'in (2008a, s. 423) ve Kozaklı'nın (2006, s. 97) üniversite öğrencileriyle yaptıkları çalışma sonuçlarıyla ve Eskin'in $(2001$, s.10) ergenlerle yaptı̆̆1 çalışma bulgusuyla örtüşmektedir. Cramer ve Neyedley'e (1998) göre, erkekler toplumsal baskılar nedeniyle zayıflık duygularını bastırmaktadır, bu nedenle de yalnızlı̆̆ın dolaylı olarak ölçülmesi gerekmektedir (aktaran; Kozaklı, 2006, s. 98). Ancak, UCLA Yalnızlık Ölçeği’nin yalnızlı düzeyini doğrudan ölçüyor olması ve cinsiyetçi sosyal rollerin göz ardı edilmesi böyle bir sonuca neden olmuş olabilir (Kozaklı, 2006, s. 98).

Araştırmadan elde edilen bir başka sonuç ise, yalnızlık ile medeni durum arasında anlamlı bir farklılaşmanın olmamasıdır. Yakut ve Certel (2016)'in öğretmenlerle yapmış oldukları çalısmada da, öğretmenlerin yalnızlık düzeylerinin evli veya bekâr olmalarına göre anlamlı olarak değişmediği saptanmıştır(s. 89). Evli olmamak veya romantik bir ilişkinin olmaması yalnızlık için bir risk faktörüdür, bireyi yalnızlı̆̆a yatkın kılabilir. Ancak, bireyi doğrudan yalnızlaştırdıkları söylenemez (Kozaklı, 2006, s. 31).

Ayrıca yine araştırma sonuçlarına göre, yalnızlık ile çalışma durumu arasında da anlamlı bir ilişki bulunamamıştır. Aynı şekilde, Yılmaz, Yılmaz ve Karaca (2008, s.75-76) da, üniversite öğrencilerinin bir işte çalışıp çalışmama durumlarının yalnızlıkla anlamlı bir şekilde ilişkili olmadığını bulmuşlardır. Kara, Kelecek ve Aşçı'nın, (2014, s. 64) sporcu eşleriyle yaptıkları çalışmada da benzer bir sonuca rastlanmıştır. Bir işte çalışıyor olma, bireye sosyalleşme imkanı sağlayabileceği gibi, bireyin kendini işte yalnız bulmasıyla da sonuçlanabilmektedir. Bu nedenle, bu durumun "iş yerinde yalnızlık" çalışmalarıyla birlikte değerlendirilmesi gerektiği düşünülmektedir.

Bireylerin yalnızlık düzeyleri üzerinde etkili olduğu düşünülen bir başka değişken ise, gelir düzeyidir. Nitekim araştırmada, yalnızlık düzeyinin gelir düzeyine göre farklılaştığı görülmüştür. Yalnızlık düşük, orta ve yüksek gelir düzeyiyle paralel bir şekilde artış göstermiştir. Literatüre bakıldığında, gelir düzeyi yalnızlı̆̆1 etkileyen en önemli faktör olarak karşımıza çıkmaktadır. Gelir düzeyi yüksek olan grubun alım gücü yüksektir. Ancak, para kazanmak emek ve zaman gerektirdiği için çalışan insan, kendine dahi vakit ayıramamakta, işler yaşama taşmaktadır (Gün, 2006, s. 30). Ayrıca yüksek gelire sahip insanların, kayıtsız bağlanma stiline sahip oldukları, duygusal ilişki kurmaktan kaçındıkları, kendi kendine yetme düşüncesine sahip oldukları ve güven problemi yaşadıkları da ifade edilmiştir (Erözkan, 2004, s. 170).

Araştırma sonuçları eğitim durumu ve yalnızlık bağlamında incelendiğinde ise, elde edilen bulgular, ön lisans mezunlarının yalnızlık düzeylerinin hem lisans hem de lisansüstü mezunlarının yalnızlık düzeylerinden anlamlı olarak farklılaştığını göstermiştir. Ön lisans mezunları, lisans ve lisansüstü 
mezunlarına göre daha yalnız bulunmuştur. Eğitimli insanların, yalnızlığı daha iyi tolere ettikleri, yalnızlıkla baş etmede alternatif çözüm yolları geliştirebildikleri düşünülmektedir (Yıldırım vd., 2011, s. 29).

Araştırma sonuçları öz-tiksinme bağlamında ele alındığında, katılımcıların öz-tiksinme düzeyleri ile medeni durumları, eğitim düzeyleri, çalışma durumları ve gelir düzeyleri arasında anlamlı bir ilişki bulunamazken; katılımcıların öz-tiksinme düzeyleri ile cinsiyetleri arasında anlamlı bir iliş̧ki olduğu görülmüştür. Erkeklerin öz-tiksinme düzeyleri, kadınlardan daha yüksek bulunmuştur. Yabancı literatür incelendiğinde, yapılan az çalışma olmakla birlikte, kadınların daha fazla öz-tiksinme düzeyi bildirdikleri belirtilmiştir (Palmeira vd., 2019,s. 7; Lazuras vd, 2019, s. 151; Ille vd., 2014, s. 942). Literatür, kadınların daha fazla tiksinme hassasiyeti gösterdiklerini (Schienle vd., 2005, s. 278-279), erkeklerden daha fazla öz eleştiri ve daha az öz şefkat becerisine sahip olduklarını göstermektedir (Neff, 2003, s. 240-241; Yarnell vd., 2015, s. 500). Ancak, kadınların "fedakar" olarak sosyalleştirilmesinin kendilerine şefkat duymalarına da etki edebileceğini söyleyenler de vardır (Yarnell vd., 2015, s. 500). Nitekim bu konuya ilişkin özellikle kendi kültürümüzde yapılmış başka çalışmalara ihtiyaç olduğu söylenebilir.

Çoklu regresyon analizi sonuçları incelendiğinde ise; yalnızlık ve öz-tiksinmenin yaşam doyumu üzerindeki etkisi anlamlı bulunmuştur. Öz-tiksinme ve yalnızlık, yaşam doyumunu birlikte \%13 oranında açıklamışıır. Regresyon sonuçlarına göre ise, katılımcıların yalnızlık ve öz-tiksinme düzeyleri arasında düşük düzeyde, ters yönlü, anlamlı bir ilişki bulunduğu söylenebilir. Yani katılımcıların öz-tiksinme düzeyleri arttıkça, yalnızlık düzeyleri azalma göstermiştir. Yabancı literatürde yapılmış araştırmalarda da benzer bulgulara rastlanmıştır (Ypsilanti, 2018, s. 2; Ypsilanti vd., 2019, s. 111). Brake ve diğgerlerine göre (2017, s. 2), içsel yönelimli iğrenme olarak tanımlanan öz-tiksinme, kişinin kendisinden ve davranışlarından hoşnutsuzluk halidir. Sosyal ve ahlaki normların ihlali ile tetiklenen 'ahlaki' ve sosyal tiksinme ile ilişkilidir. Bu bakımdan öz-tiksinme, bir kişinin kişilerarası çekiciliği ve sosyal kabulünün bir kontrol mekanizması olarak işlev görebilir (Ille vd., 2014, s. 938).

Yine regresyon analizi sonuçlarına göre; yalnızlık ile yaşam doyumu arasında düşük düzeyde, pozitif ve anlamlı bir ilişki olduğu dikkati çekmiştir. Yani katılımcıların yalnızlıkları arttıkça, yaşam doyumları da yükselmiştir. Literatür incelendiğinde bu bulgunun tersine, yaşam doyumu ile yalnızlık arasında negatif ilişsi bulunan, farklı örneklemlerle yapılmış birçok çalışmaya rastlanmışır (Dost, 2007, s. 139; Kapıkıran ve Yağc1, 2012, s. 743; Özkaya, 2017, s.32; Fernández-Alonso vd., 2012, s. 90). İlişskinin bulunmadığ1 çalışmalar da vardır (Kara, Kelecek ve Aşçı, 2014, s. 62). Araştırma sonuçlarına göre, katılımcıların yaşam doyumu ve öz-tiksinme puanları arasında düşük düzeyde, negatif ve anlamlı bir ilişkinin olduğu görülmüştür. Yani katılımcıların öz-tiksinme düzeyleri yükseldikçe, yaşam doyumları düşmektedir. Alan yazın incelendiğinde, yaşam doyumu ve öz-tiksinme ile ilgili yapılmış herhangi bir çalışmaya rastlanmamıştır. Ancak, Powell, Simpson ve Overton (2015b) kişinin vücuduna yönelik artan tiksinti duygusunun, psikolojik iyi olma ile olumsuz ilişkisi olduğunu bildirmiştir (s. 99).

$\mathrm{Bu}$ araştırma, örneklem açısından bazı sınırlılıklar göstermektedir. Araştırmanın örneklemi, 18 yaş ve üzeri bireylerle sınırlıdır. Ayrıca araştırmadan elde edilen veriler, UCLA Yalnızlık Ölçeği Kısa Form, Yaşam Doyumu Ölçeği, Öz-tiksinme Ölçeği’nin ölçtüğü özelliklerle sınırlıdır. Öz-tiksinme kavramının, alanyazın çalışmalarında çok az çalışıldığı anlaşılmaktadır. Bu kavramın, derinlemesine çalışılması, kavramsal ve olgusal anlamda araştırmalar yapılması, deneysel desenlerle psiko-eğitim çalısmaları yapılması ve öz-tiksinme kavramının kültüre dayalı boyutlarının araştırılması önerilmektedir.

\section{Etik Beyan}

"Yetişkinlerin Yaşam Doyumu, Yalmąlk, ve Öz-tiksinme Düzeyleri Arasindaki İliskkinin İncelenmesi” başlıklı çalışmanın yazım sürecinde bilimsel kurallara, etik ve alıntı kurallarına uyulmuş; toplanan veriler üzerinde herhangi bir tahrifat yapilmamış ve bu çalışma herhangi başka bir akademik yayın ortamına değerlendirme için gönderilmemiştir. Bu araştırmanın verileri 01.01.2020 tarihinden önce toplandığı için etik kurul kararı zorunluluğu taşımamaktadır.

\section{Kaynakça}

Ağırman, E. ve Gençer, M. Z. (2017). Huzurevinde, evde ailesiyle ve yalnız yaşayan yaşılı bireylerde depresyon, yalnızlık hissi düzeylerinin karşılaştırılması. Cağdaş Tip Dergisi, 7(3), 234-240.

Akman, G. (2019). Faz̧la kilolu ve obez nireylerde beden algisi, benlik saygzsı ve algzlanan sosyal desteğin yaşam doyumuyla iliskisinin incelenmesi (Yüksek Lisans Tezi). Maltepe Üniversitesi, Sosyal Bilimler Enstitüsü, İstanbul. 
Arslangiray, N. (2013). Üniversite ögrencilerinde beden imajinn yordayzclar olarak bă̆lanma stilleri ve toplumsal cinsiyet rolleri. (Yüksek Lisans Tezi). Hacettepe Üniversitesi, Sosyal Bilimler Enstitüsü, Ankara.

Avşaroğlu, S., Deniz, M. E. ve Kahraman, A. (2005). Teknik öğretmenlerde yaşam doyumu iş doyumu ve mesleki tükenmişlik düzeylerinin incelenmesi. Selçk Üniversitesi Sosyal Bilimler Enstitüsü Dergisi, (14), 115-129.

Avşaroğlu, S. ve Okutan, H. (2018). Zihin engelli çocuğu olan ailelerin yaşam doyumları, iyimserlik ve psikolojik belirti düzeylerinin incelenmesi. Manas Sosyal Arastırmalar Dergisi, 7(1), 59-76.

Avşaroğlu, S. ve Koç, H., (2019). Yaşam doyumu ile sıkıntıyı tolere etme arasındaki ilişkide iyimserliğin aracı etkisi. Türk Psikolojik Danısma ve Rebberlik Dergisi, 9(53), 565-588.

Bahtiyar, B. ve Yıldırım, A. (2019). Öz-tiksinme ölçeği-revize formu: Türkçe uyarlama, geçerlik ve güvenirlik çalışması. Klinik Psikiyatri Dergisi, 22(3), 304-315.

Baltac1, Ö. (2019). The predictive relationships between the social madia addiction and social anxiety, loneliness and happines. International Journal of Progressive Education, 15(4), 73-82.

Brake, C. A., Rojas, S. M., Badour, C. L., Dutton, C. E. ve Feldner, M. T. (2017). Self-disgust as a Potential mechanism underlying the association between PTSD and suicide risk. Journal of Anxiety Disorders, (47), 1-9.

Buluş, M. (1997). Üniversite öğrencilerinde yalnızlık. Pamukkale Üniversitesi Ë̆itim Fakültesi Dergisi, 3(3), 82-90.

Certel, H., Yakut, S., Yakut, İ. ve Gülsün, B. (2016). Öğrencilerde yalnızlı problemi. Journal of the Human \& Social Science Researches, 5(8), 3069-3084.

Chapman, H. A. ve Anderson, A. K. (2012). Understanding disgust. Annals of the New York Academy of Sciences, 1251(1), 62-76.

Chapman, H. A., Kim, D. A., Susskind, J. M. ve Anderson, A. K. (2009). In bad taste: Evidence for the oral origins of moral disgust. Science, 323(5918), 1222-1226.

Chow, H. P. (2005). Life satisfaction among university students in a canadian prairie city: A multivariate analysis. Social indicators research, 70(2), 139-150.

Çeçen, A. R. (2008a). Öğrencilerinin cinsiyetlerine ve ana-baba tutum algılarına göre yalnızlık ve sosyal destek düzeylerinin incelenmesi. Türk Ĕ̈itim Bilimleri Dergisi, 6(3), 415-431.

Çeçen, A. R. (2008b). Üniversite öğrencilerinde yaşam doyumunu yordamada bireysel bütünlük (Tutarlılık) duygusu, aile bütünlük duygusu ve benlik saygis1. Journal of Theory \& Practice in Education (JTPE), 4(1), 19-30.

Çelebi, G. Y. ve Çelebi, B. (2018). Lise öğrencilerinin yaşam doyumu düzeylerinin çeşitli değişkenler açısından incelenmesi. Erciyes Journal of Education, 2(2), 1-15.

Çevik, N. K. ve Korkmaz, O. (2014). Türkiye'de yaşam doyumu ve iş doyumu arasındaki ilişkinin iki değişkenli sıralı probit model analizi. Niğde Üniversitesi İktisadi ve İdari Bilimler Fakültesi Dergisi, 7(1), 126-145.

Dağlı, A. ve Baysal, N. (2016). Yaşam doyumu ölçeğinin Türkçe’ye uyarlanması: Geçerlik ve güvenirlik çalışması. Electronic Journal of Social Sciences, 15(59), 1250-1262.

Demirci, İ. ve Ekşi, F. (2015). Ergenler için beş boyutlu iyi oluş modeli: EPOCH ölçeği’nin Türkçe formunun geçerliği ve güvenirliği. Gençlik Arastırmalar Dergisi, 3(3), 9-30.

Demirel, C. (2018). Yetişkinlerde bağlanma stillerinin mutluluk, yaşam doyumu ve depresyon ile ilişkisinin incelenmesi (Yüksek Lisans Tezi). Işık Üniversitesi, Sosyal Bilimler Enstitüsü, İstanbul.

Deniz, M., Arslan, C., Özyeşil, Z. ve İzmirli, M. (2012). Öz-anlayış, yaşam doyumu, negatif ve pozitif duygu: Türk ve diğer ülke üniversite öğrencileri arasında bir karşılaştırma. Mebmet Akif Ersoy Üniversitesi Eğitim Fakültesi Dergisi, 12(23), 428-446.

Diener, E. D., Emmons, R. A., Larsen, R. J. ve Griffin, S. (1985). The satisfaction with life scale. Journal of Personality Assessment, 49(1), 71-75.

Diener, E., Suh, E. M., Lucas, R. E. ve Smith, H. L. (1999). Subjective well-being: Three decades of Progress. Psychological Bulletin, 125(2), 276-302.

Doğan, T., Çötok, N. A. ve Tekin, E. G. (2011). Reliability and validity of the Turkish version of the UCLA loneliness scale (ULS-8) among university students. Procedia-Social and Behavioral Sciences, 15, 2058-2062.

Dost, M. T. (2007). Üniversite öğrencilerinin yaşam doyumunun bazı değisskenlere göre incelenmesi. Pamukekale Üniversitesi Ë̆itim Fakültesi Dergisi, 22(22), 132-143.

Erdinç, İ. (2018). Evli çftlerde, evlilik uyumu, cinsel yaşam doyumu ve yaşam doyumu arasindaki ilişkinin incelenmesi (Yüksek Lisans Tezi). İstanbul Gelişim Üniversitesi, Sosyal Bilimler Enstitüsü, İstanbul.

Erözkan, A. (2004). Lise öğrencilerinin bağlanma stilleri ve yalnızlı düzeylerinin bazı değişkenlere göre incelenmesi. Atatürk Üniversitesi Sosyal Bilimler Enstitüsü Dergisi, 4(2), 155-175.

Eryilmaz, A. ve Öğülmüş, S. (2010). Ergenlikte öznel iyi oluş ve beş faktörlü kişilik modeli. Journal of Kirsehir Education Faculty, 11(3), 189-203.

Eskin, M. (2001). Ergenlikte yalnızlık, baş etme yöntemleri ve yalnızlığın intihar davranışı ile ilişkisi. Klinik Psikiyatri, 4(5), 5-11.

Feridun, K. ve Birol, Z. N. (2018). Üniversite öğrencilerinin yalnızlık ve mükemmeliyetçilik düzeyleri arasındaki ilişkide duygusal zekânın aracılık rolü. Kastamonu Ë̆itim Dergisi, 26(6), 1793-1802.

Fernández-Alonso, A. M., Trabalón-Pastor, M., Vara, C., Chedraui, P. ve Pérez-López, F. R.(2012). Life satisfaction, loneliness and related factors during female midlife. Maturitas, 72(1), 88-92.

Fox, J. R. E. (2009). Eating disorders and emotions. Clinical Psychology \& Psychotherapy, 16(4), 237-239.

Gülcan, A. ve Bal, P. N. (2014). Genç yetişkinlerde iyimserliğin mutluluk ve yaşam doyumu üzerindeki etkisinin incelenmesi. Asian Journal of Instruction, 2(1), 41-52. 
Gün, F. (2006). Kent kültüründe yalnı̨lk duygusu (Yüksek Lisans Tezi). Ankara Üniversitesi, Sosyal Bilimler Enstitüsü, Ankara.

Haidt, J., McCauley, C. R. ve Rozin, P. (1994). Individual differences in sensitivity to disgust: Ascale sampling seven domains of disgust elicitors. Personality and Individual Differences, 16(5), 701-713.

Haskan, A., O. ve Yildırım, İ. (2014). Violence tendency, loneliness and social support among adolescents. Hacettepe Unversity Journal of Education, 29(1), 157-168.

Hawley, P. ve Vaughn, B. (2003). Aggression and adaptation: The bright side to bad behavior. Introduction to special volume. Merrill-Palmer Quarterly, 49(3), 239-244.

Hosseinkhanzadeh, A. A. ve Taher, M. (2013). The relationship between personality traits with life satisfaction. Sociology Mind, 3(01), 99-105.

Ille, R., Schöggl, H., Kapfhammer, H. P., Arendasy, M., Sommer, M. ve Schienle, A. (2014). Self-disgust in mental disorders symptom related or disorder specific?. Comprehensive Psychiatry, 55(4), 938-943.

İncekara, T. (2018). Üniversite ögrencilerinde vücut algısı ile yaşam doyumu arasindaki iliş̧inin incelenmesi (Doktora Tezi). Haliç Üniversitesi, Sosyal Bilimler Enstitüsü, İstanbul.

İzgiş, H. (2019). Bir grup ögretmenin alguladıklar sosyal destek ve yaşam doyumu ile depresyon arasindaki ilişkinin incelenmesi (Yüksek Lisans Tezi). Iş1k Üniversitesi, Sosyal Bilimler Enstitüsü, İstanbul.

Johnson-Laird, P. N. ve Oatley, K. (1989). The language of emotions: An analysis of a semantic field. Cognition and Emotion, 3(2), 81-123.

Kapıkıran, Ş. ve Yağc1, U. (2012). Loneliness and life satisfaction of adolescents: The mediator and moderator role of playing musical İnstruments and Joining A Band. Elementary Education Online, 11(3), 738-747.

Kara, F. M., Kelecek, S. ve Aşçı, F. H. (2014). Sporcu eşlerinin yaşam doyumu ve yalnızlık düzeylerinin incelenmesi. Spor Bilimleri Dergisi, 25(2), 56-66.

Karaköse, H. B. (2019). Üniversite ögrencilerindeki akallı telefon bağımlihğgnın yaşam doyumu ve depresyon açısından incelenmesi (Yüksek Lisans Tezi). İstanbul Gelişim Üniversitesi, Sosyal Bilimler Enstitüsü, İstanbul.

Kermen, U., Tosun, N. İ. ve Doğan, U. (2016). Yaşam doyumu ve psikolojik iyi oluşun yordayıcısı olarak sosyal kayg1. Ë̆itim Kuram ve Uygulama Arastırmalar Dergisi, 2(1), 20-29.

Keser, A. (2005). Çalışma yaşamı ile yaşam doyumu ilişkisine teorik bakış. İstanbul Üniversitesi İktisat Fakültesi Mecmuasi, 55(1), 897-913.

Kozaklı, H. (2006). Üniversite ögrencilerinde yalnı̨lı ve sosyal destek düzeyleri arasındaki ilişkilerin karşılasstırlması (Yüksek Lisans Tezi). Mersin Üniversitesi Sosyal Bilimler Enstitüsü, Mersin.

Kula, S. ve Çakar, B. (2015). Maslow ihtiyaçlar hiyerarşisi bağlamında toplumda bireylerin güvenlik alg1sı ve yaşam doyumu arasındaki ilişki. Bartın Üniversitesi III BF Dergisi, 6(12), 191-210.

Lachmann, B., Sindermann, C., Sariyska, R. Y., Luo, R., Melchers, M. C., Becker, B. ve Montag, C. (2018). The role of empathy and life satisfaction in internet and smartphone use disorder. Frontiers in Psychology, (9), 398. https://doi.org/10.3389/fpsyg.2018.00398

Lazuras, L., Ypsilanti, A., Powell, P. ve Overton, P. (2019). The roles of impulsivity, self-regulation, and emotion regulation in the experience of self-disgust. Motivation and Emotion, 43(1), 145-158.

Moncrieff-Boyd, J., Byrne, S. ve Nunn, K. (2014). Disgust and anorexia nervosa: Confusion between self and nonself. Advances in Eating Disorders: Theory, Research and Practice, 2(1), 4-18.

Neff, K. D. (2003). The development and validation of a scale to measure self-compassion. Self and Identity, 2(3), 223250.

Overton, P. G., Markland, F. E., Taggart, H. S., Bagshaw, G. L. ve Simpson, J. (2008). Self-disgust mediates the relationship between dysfunctional cognitions and depressive symptomatology. Emotion, 8(3), 379-90.

Özkaya, G. (2017). Üniversite ögrencilerinin yalnıðlık düzeyleri ile umutsųluk ve yaşam doyumu arasindaki ilişki (Doktora Tezi). Haliç Üniversitesi, Sosyal Bilimler Enstitüsü, İstanbul.

Özkul, A. S. ve Alparslan, A. M. (2019). Yaşam doyumunu artıran motivasyon kaynağı: Düşünme-anlama ihtiyac1. Itobiad: Journal of the Human and Social Science Researches, 8(4), 3272-3288.

Palmeira, L., Pinto-Gouveia, J. ve Cunha, M. (2019). The role of self-disgust in eating psychopathology in overweight and obesity: Can self-compassion be useful?. Journal of Health Psychology, 24(13), 1807-1816.

Powell, P. A., Overton, P. G. ve Simpson, J. (2014). The revolting self: An interpretative phenomenological analysis of the experience of self-disgust in females with depressive symptoms. Journal of Clinical Psychology, 70(6), 562578.

Powell, P. A., Overton, P. G. ve Simpson, J. (Ed.). (2015a).The revolting self: Perspectives on the psychological, social, and clinical implications of self-directed disgust. Great Britain: Carnac Books.

Powell, P. A., Simpson, J. ve Overton, P. G. (2015b). Self-affirming trait kindness regulates disgust toward one's physical appearance. Body Image, 12, 98-107.

Rozin, P. ve Fallon, A. E. (1987). A perspective on disgust. Psychological Review, 94(1), 23-41.

Rozin, P., Millman, L. ve Nemeroff, C. (1986). Operation of the laws of sympathetic magic in disgust and other domains. Journal of Personality and Social Psychology, 50(4), 703-712.

Rozin, P., Haidt, J., McCauley, C., Dunlop, L. ve Ashmore, M. (1999). Individual differences in disgust sensitivity: Comparisons and evaluations of paper-and-pencil versus behavioral measures. Journal of Research in Personality, 33(3), 330-351. 
Saltan, A. ve Küçük, M. K. (2018). Yaşlı bireylerde yaşanılan yer ile yalnızlık durumu arasındaki ilişkinin araştır1lması. Yaşam Becerileri Psikoloji Dergisi, 2(4), 191-198.

Schienle, A., Schäfer, A., Stark, R., Walter, B. ve Vaitl, D. (2005). Gender differences in the processing of disgust-and fear-inducing pictures: an fmr1 study. Neuroreport, 16(3), 277-280.

Seligman, M. E. P. (2007). Gerçek mutluluk. kahcı doyum potansiyeliniz̨i geliş̧irmek için yeni olumlu psikolojinin kullanılması. Ankara: HYB, 1-338.

Simpson, J., Hillman, R., Crawford, T. ve Overton, P. G. (2010). Self-esteem and self-disgust both mediate the relationship between dysfunctional cognitions and depressive symptoms. Motivation and Emotion, 34(4), 399-406.

Singh, K. ve Jha, S. D. (2008). Positive and negative affect, and grit as predictors of happiness and life satisfaction. Journal of the Indian Academy of Applied Psychology, 34(2), 40-45.

Smith, N. B., Steele, A. M., Weitzman, M. L., Trueba, A. F. ve Meuret, A. E. (2015). Investigating the role of selfdisgust in nonsuicidal self-injury. Archives of Suicide Research, 19(1), 60-74.

Spreckelsen, P. V., Glashouwer, K. A., Bennik, E. C. ve Wessel, I. (2018). Negative body image: Relationships with heightened disgust propensity, disgust sensitivity, and self-directed disgust. Plos One, 13(6), 1-15.

Staudinger, U. M., Fleeson, W. ve Baltes, P. B. (1999). Predictors of subjective physical health and global well-being: similarities and differences between the united states and germany. Journal of Personality and Social Psychology, 76(2), 305-319.

Stewart, R. A. (1976). Satisfaction in stages of the life cycle, levels of general happiness and frequency of peak experience. Social Behavior and Personality: An International Journal, 4(1),105-108.

Şahin, A. (2019). Üniversite öğrencilerinde bilinçli farkındalık ile yaşam doyumu ve iyi oluş arasındaki ilişkiler. Üsküdar Üniversitesi Sosyal Bilimler Dergisi, (8), 151-176.

Şimşek, A. ve Büyükkıdık, S. (2015). Emekli öğretmenlerin yaşam doyumlarına ilişkin görüşlerinin incelenmesi. Mehmet Akif Ersoy Üniversitesi Ë̆itim Bilimleri Enstitüsü Dergisi, 4(6), 19-41.

Uygur, S. S. (2018). Yaşam doyumunun yordanmasında kendini açma ve sosyal desteğin rolü. Ulusal Eğitim Akademisi Dergisi, 2(1), 16-33.

Uzuner, M. E. ve Karagün, E. (2014). Rekreatif amaçlı spor yapan bireylerin yalnızlık düzeylerinin incelenmesi. Kocaeli Üniversitesi Sosyal Bilimler Dergisi, (27), 107-120.

Ülker Tümlü, G. ve Recepoğlu, E. (2013). Üniversite akademik personelinin psikolojik dayanıklılık ve yaşam doyumu arasındaki ilişki. Yükesekögretim ve Bilim Dergisi, 3(3), 205-213.

Ümmet, D. (2017). Genel psikolojik sağlık ile yaşam doyumu arasındaki ilişkide evlilik uyumunun aracı rolü. Itobiad: Journal of the Human \& Social Science Researches, 6(1), 159-175.

Ünal, S., Karlıdağ, R. ve Yoloğlu, S. (2001). Hekimlerde tükenmişlik ve iş doyumu düzeylerinin yaşam doyumu düzeyleri ile ilişkisi. Klinik Psikiyatri, 4(2), 113-118.

Yakut, S. ve Certel, H. (2016). Öğretmenlerde yalnızlık düzeyinin çeşitli değişkenler açısından incelenmesi. Birey ve Toplum Sosyal Bilimler Dergisi, 6(1), 69-94.

Yalçın, İ. (2015). İyi oluş ve sosyal destek arasındaki ilişkiler: Türkiye'de yapılmış çalışmaların meta analizi. Türk Psikiyatri Dergisi, 26(1), 21-32.

Yarnell, L. M., Stafford, R. E., Neff, K. D., Reilly, E. D., Knox, M. C. ve Mullarkey, M. (2015). Meta-analysis of gender differences in self-mompassion. Self and Identity, 14(5), 499-520.

Yıldırım, B., Engin, E. ve Yıldırım, S. (2011). Alkol ve madde bağımlılarında yalnızlık ve etki eden faktörler. Journal of Psychiatric Nursing, 2(1), 25-30.

Yıldız, M. (2016). Üniversite öğrencilerinde duygusal zekâ yaşam doyumu ve depresyonun cinsiyet ve sınıf seviyelerine göre etkileri. Opus Uluslararası Toplum Arastırmalar Dergisi, 6(11), 451-474.

Yıldız, M. A. ve Baytemir, K. (2016). Evli bireylerde evlilik doyumu ile yaşam doyumu arasındaki ilişkide benlik sayg1sının arac1lı̆̆ı. Inönü Üniversitesi Eğitim Fakültesi Dergisi, 17(1), 67-80.

Yılmaz, E. ve Aslan, H. (2013). Öğretmenlerin iş yerinde yalnızlıkları ve yaşam doyumları arasındaki ilişkinin incelenmesi. Pegem Ĕ̈itim ve Ögretim Dergisi, 3(3), 59-69.

Yılmaz, E., Yılmaz, E. ve Karaca, F. (2008). Üniversite öğrencilerinin sosyal destek ve yalnızlık düzeylerinin incelenmesi. Genel Tip Dergisi, 18(2), 71-79.

Ypsilanti, A. (2018). Lonely but Avoidant the unfortunate juxtaposition of loneliness and self-disgust. Palgrave Communications, 4(1), 1-4.

Ypsilanti, A., Lazuras, L., Powell, P. ve Overton, P. (2019). Self-disgust as a potential mechanism explaining the association between loneliness and depression. Journal of Affective Disorders, 243, 108-115.

\section{EXTENDED ABSTRACT}

When the literature is examined, the concept of life satisfaction is mostly examined as a cognitive component under the structure of "subjective well-being". Subjective well-being reflects all reactions and evaluations of people towards their lives, the degree of thinking and feeling that it is going well. Insufficient and individually unsatisfactory social experiences in individuals' relationships can affect their lives at different levels. This can cause individuals to isolate themselves from society and feel lonely. The primary purpose of this study is to contribute to the literature in finding the sources of life satisfaction. In this study, the concepts of life satisfaction, loneliness and self-disgust will be discussed in detail. One of 
the most prominent concepts in positive psychology studies is life satisfaction. Satisfaction; people's hunger, thirst, sexuality and so on. basic biological needs or curiosity, love, sincerity, success, etc. It is the elimination of cognitive and psychological needs such as providing a balance state. One of the concepts whose effect on life satisfaction is investigated in the study is loneliness. Loneliness stands out as one of the most important problems of the modern world, symbolizing the dark side of the human being, making life unbearable and waiting for enlightenment. Another concept addressed in the research is self-disgust. When the relevant literature was examined, it was observed that self-disgust was studied together with mental health disorders such as sexual disorders, eating disorders and social anxiety. The idea that disgust can be directed incompatibly with the self has empirical roots within clinical psychology and has been described as a distinct feeling that includes experiences of extreme hate, with an emphasis on the self, body, and actions of the person, especially those that violate the so-called desired self. This research; It was conducted to reveal to what extent adults' levels of loneliness and self-disgust explain their life satisfaction.

In the study, relational scanning model, one of the quantitative research methods, was used to examine the relationship between life satisfaction, loneliness and self-disgust levels of adults. Research; It was conducted with 634 people. 353 of the participants (56\%) are women and $281(44 \%)$ of them are men. In this study, "UCLA Loneliness Scale short form", "Life Satisfaction Scale", "Self-Sufficiency Scale" and "Personal Information Form" developed by the researchers who conducted the study were used to obtain data. The research data were collected via Google forms in 2019 and the SPSS 22.00 package program was used for analysis.

Findings and Comments:

1. It has been revealed that the effect of loneliness and self-disgust on life satisfaction is significant. $\mathrm{F}(2,50), \mathrm{p}<.05, \mathrm{R} 2=.13$, adj. $\mathrm{R} 2=.13$.

2. There is also an inverse low level relationship between self-disgust and loneliness $(r=-0.18, p$ $<.05)$. As the level of self-disgust increases, loneliness decreases, and as loneliness decreases, selfdisgust increases.

3. While the mean scores of women from the life satisfaction scale are $16.41(\mathrm{n}=353$; $\mathrm{SD}=3.86$ ), the average scores for men from the life satisfaction scale are $17.14(\mathrm{n}=281 \mathrm{SD}=4.24)$. Based on this, we can say that the life satisfaction of men differs significantly from women.

4. It is seen that the self-disgust level of men differed significantly from women. Men's self-disgust ranking mean (349.02) is higher than women's (292.41).

5. It is seen that the self-disgust level of men differed significantly from women. Men's self-disgust ranking mean (349.02) is higher than women's (292.41). 6- There is a significant difference between those who have a job and those who do not. While the average score of the employees from the life satisfaction scale was $17.09(\mathrm{n}=377$; $\mathrm{SD}=3.80)$, the average score obtained from the life satisfaction scale for the unemployed was $16.22(\mathrm{n}=328 ; \mathrm{SD}=4.33$ ).

6. The scores obtained from the loneliness scale do not show a significant difference according to marital status. $(\mathrm{U}=44401.00, \mathrm{p}>.05)$.

7. ANOVA test revealed that satisfaction with life shows significant differences between income levels, $\mathrm{F}(2,631)=27.88, \mathrm{p}<.05$ When life satisfaction is examined according to income level, it is low $(X=13.72, S D=4,38)$, medium level $(X=16.89, S D=3.94)$ and high level $(X=18.80$, $\mathrm{SD}=3.65)$.

8. According to the result of Kruskal Wallis, it has been revealed that the loneliness levels of the participants differ significantly between the groups. $\left(\chi^{2}(s d=2, n=634)=18.51 \mathrm{p}<.05\right.$.

In this study, the predictive power of adults' levels of loneliness and self-disgust on their life satisfaction was examined in terms of various variables. According to the results, the levels of loneliness and self-disgust of adults were found to be important predictors of their life satisfaction. In the study, it was found that the life satisfaction of adult individuals differs according to gender. According to the results of the research obtained, life satisfaction of men was found to be higher than women. Again, in the study, it was found that the life satisfaction of adult individuals differs according to marital status. The obtained findings revealed that the life satisfaction of married individuals is significantly higher than single individuals. When the research findings are examined in terms of life satisfaction and income level, it shows that there is a significant relationship between life satisfaction and income level. Again, in relation to economic well-being, the study found that working status also differentiates life satisfaction. According 
to the findings, the life satisfaction of the employees is significantly higher than those who do not work. Another variable that shows its effect on the life satisfaction of the participants in the study is education status. According to the findings obtained, life satisfaction of graduate graduates was found to be higher than associate degree graduates. Also, again, according to the results of the research, no significant relationship was found between loneliness and working status. Another variable that is thought to have an effect on individuals' loneliness is the level of income. As a matter of fact, it has been observed in the study that the level of loneliness differs according to the income level. Loneliness has increased in parallel with low, middle and high income levels. Finally, according to the research results, it was observed that there was a low level, negative and significant relationship between the life satisfaction and self-disgust scores of the participants. In other words, the higher the self-disgust levels of the participants, the lower their life satisfaction. 